\title{
FROM PRE-COLONY TO POST-COLONY \\ Continuities and Discontinuities in \\ Political Power Relations and Governance in Botswana
}

\section{Monageng Mogalakwe}

\author{
Dr Monageng Mogalakwe is senior lecturer in the \\ Department of Sociology at the University of Botswana \\ P/Bag UB 00705, Gaborone, Botswana \\ Tel: +267355 2678 \\ e-mail: Mogalakwe@mopipi.ub.bw
}

\begin{abstract}
Botswana has been praised for its adherence to parliamentary democracy and good governance and as the best hope for Africa. However, a closer examination of its much vaunted democracy reveals a top-down presidential system in which an unelected president has more power and authority than an elected Parliament and the country's parliamentary system does not ensure and facilitate broad-based and inclusive political participation in the decision-making process. This resembles the political power relations and governance systems of both the pre-colonial era under the chiefs and the colonial era of the resident commissioners.
\end{abstract}

\section{INTRODUCTION}

It is common cause that human societies comprise a set of social institutions economic, educational, family, political and religious - each of which encapsulates social practices which are regularly and continuously repeated, reaffirmed and maintained by social norms and values. The texture of such institutions may vary within the same or different epochs while the content remains the same, and it is this variability that gives societies their particular form or character. Any given society is, therefore, a complex refraction of the articulation of its social institutions. Following Max Weber, that doyen of political sociology, modernisation theory has posited that variations within the political institution involve a transition from a 'traditional power and authority system' to what is characterised as a 'legal-rational power and authority system'. 
The definition of traditional power and authority systems relates to the exercise of political power and authority legitimated by individuals' acquiescence in a system of governance that has become habitual or customary (Jary \& Jary 1991). On the other hand, the definition of a legal rational power and authority system relates to the exercise of political power and authority which rests on a belief in the legality of enacted rules and those, such as elected representatives, who achieve authority under these rules (Jary \& Jary 1991). This paper examines the dynamics of the Tswana political institution from the pre-colonial period through the colonial period to the post-colonial period. It is argued that these periods show both a continuity and discontinuity in the exercise of political power and authority, namely a top-down centralised power structure, and that political exclusivity in decision-making characterises all three periods. As in the precolonial and colonial periods and even in the post-colonial 'democratic' period, characterised by regular elections, political power and authority are still centralised, concentrated and top-down and the advent of the parliamentary system has not allowed for or facilitated real popular participation in decisionmaking in Botswana.

\section{POLITICAL POWER AND AUTHORITY IN THE PRE-COLONIAL ERA}

In the Tswana traditional authority system the highest organ of the state was the kgotla, a 'national assembly' which was presided over by the kgosi, a king or presidential monarch (Crowder 1988) who was patrilineally descended from the morafe (nation)'s purported founder. The kgosi had extensive executive, administrative and judicial powers and was also the religious and spiritual leader and an intermediary between the people and their ancestors. It was at the kgotla that 'national' issues were debated and decisions were made.

Although in principle every adult had the right to make a contribution to the debates, in practice the kgotla excluded those such as commoners, women, settlers, and ethnic minorities who could be characterised as subaltern social groups (Gramsci 1973).

The kgotla was dominated by a few people, preeminently members of the royal family, the aristocracy, and the kgosi's advisers. These men were also substantial cattle owners who, because of their wealth, had considerable political influence in shaping the affairs of the morafe (Mogalakwe 1997). The kgosi exercised his political power and authority through a hierarchy and network of relatives, close advisers and di-kgosana (hereditary headmen). The headmen's political power and authority were exercised at the level of the kgotlana or ward assembly. The wards assemblies were really a microcosm of the main kgotla: the headman was, of necessity, of royal descent, the first-born son of the first or favourite wife 
of the previous ward headman. The kgotlana also tended to be dominated by influential people, although to a lesser extent than the main kgotla,

Although the kgosi had considerable executive powers, and the advice of the kgotla was not binding, to ignore it could be unwise and risky and at times led to assassinations or banishment (Gossett 1986). Parsons (1975) has recorded some seven coups and counter coups in Bamagwato territory alone between 1834 and 1875. But these coups would be engineered by other members of the royal family or the aristocracy who were in the line of succession and would challenge the kgosi if the opportunity presented itself (Gossett 1986). In other words, the coups were not popular mass revolts from below. However, this ever-present threat was one of the traditional checks and balances on excessive use or even abuse of power.

The Tswana have two, seemingly contradictory, expressions. On the one hand they say kgosi e a tsalwa (a ruler is born), on the other hand they say kgosi ke kgosi $k a$ batho (the ruler rules with the will of the people) - meaning that, with all due respect, the kgosi cannot do as he pleases! What is noteworthy about the Tswana traditional political system was that the transfer of power and authority from one ruler to another was very rigid and inflexible. Succession to higher office followed the rule of primogeniture, and the first son of the first wife would succeed the father. His competence for the higher office was rarely an issue; it was assumed to derive from the political power and authority he would wield. This political practice, which served the Tswana over many centuries, was disrupted by the advent of colonialism in 1885 .

\section{POLITICAL POWER AND AUTHORITY IN THE COLONIAL ERA}

The present-day Botswana was colonised by Britain in 1885, after much hesitation. The reason for the hesitation was that the country did not have the usual attractions associated with classical colonialism, such as mineral wealth. Colonisation was, instead, the result of military strategic consideration. It was not until the British saw the threat posed by the possible alliance of the Boers of the Transvaal and the Germans in South West Africa that they decided to occupy what was then known as Bechuanaland (Maylam 1980; Mogalakwe 2006). What the British did was simply to throw a mantle of 'protection' over the chain of Tswana states of the Rolong-Ngwaketse-Kwena-Ngwato-Kgatla-Tawana (Parsons 1975) and bring all these states under one central authority, namely, the British high commissioner to the Cape Colony, based in Cape Town. The high commissioner was the substantive governor of Bechuanaland and ruled the colony by 'proclamations', that is decrees approved by the secretary of state for the colonies, and proclaimed, or published in the Government Gazette. The high commissioner's decree had only 
to be approved by the minister and not by the British Parliament. In effect, the high commissioner's 'proclamations' became the laws of the land.

This rule by proclamation lasted from 1891 to 1959, and throughout this period there was no popular participation in the formulation of the various proclamations. In 1891 the high commissioner issued a General Proclamation establishing a system of courts and personnel modelled on the system of resident magistrates that was operative in the Cape Colony. In 1909 the high commissioner issued a General Law Proclamation that stipulated that the Roman Dutch Law of the Cape Colony was to become the common law of Bechuanaland (Du Toit 1995). But this proclamation should be read with the Foreign Jurisdiction Act of 1890 which, while giving the high commissioner wide-ranging powers, carried a caveat that his powers should be exercised subject to respect for any native law and customs, except in so far as these were not incompatible with the due exercise of Her Majesty's power and jurisdiction (Du Toit 1995). The effect of this proclamation was to create a dual legal system of customary law for the 'natives' and Roman Dutch law for the 'Europeans'. This legal duality still exists in Botswana, although it no longer has any racial significance.

In another proclamation, in 1920, an African Advisory Council (AAC) was established to discuss with the resident commissioner (the high commissioner's representative) matters affecting African interests. While in principle members of the AAC were supposed to be selected at the kgotla, in practice they were chosen by the kgosi. In 1921 a European Advisory Council was established to discuss matters affecting members of the European community. Unlike that of the AAC, membership of the EAC was by popular vote every three years, using a system of qualified franchise. Although the AAC was made up of chiefs and 'councillors' chosen in kgotla, in practice there was no popular participation as these councillors were often nominated by chiefs without adequate popular participation (Mgadla \& Campbell 1989). In 1934 the high commissioner issued two proclamations, the Native Administration Proclamation and the Native Tribunal Proclamation. The first brought the chiefs under the direct control of the colonial state and the second formalised the application of the customary law in kgotla (Du Toit 1995). In 1938 the high commissioner issued the Native Treasuries Proclamation to establish tribal treasuries (Mogalakwe 2006) and in 1957 he issued a Local Councils Proclamation that established elected tribal councils.

In 1950 a Joint Advisory Council (JAC) comprising equal representation from the AAC and the EAC was established at the instigation of some of the Tswana chiefs, among them Bathoen and Tshekedi Khama. Both the AAC and the EAC were merely advisory bodies and the colonial administration was not obliged to take their advice, even though the EAC could discuss and comment on the colonial budget estimates. The JAC lasted for only ten years and was replaced by the 
Legislative Council (Legco) in 1960. Although the Legco was supposed to be an improvement, in practice it was even less representative than the advisory councils before it.

The Legco comprised 10 colonial administration officials, 10 elected European members from around the country, 10 African representatives chosen by an electoral college, four nominated members (two European and two African), and one elected Asian. Stevens (1975) points out that, in effect, 1 per cent of people of European descent had equal representation with 99 per cent of people of African descent. What this means is that, in terms of per capita representation, the vast majority of Africans were, in fact, excluded from the Legco.

It can be argued that the colonial state, which had not emerged organically from the Tswana political institution but was imposed from outside as a conquest state, aggravated and deepened the pre-colonial top-down and exclusionary system of governance that was characteristic of the chiefly era. This system, which was merely handed over to the 'new men' at the time of independence, shaped the post-colonial state. After independence the process of nation building proceeded in pretty much the same top-down manner - initiatives taken at the centre would shape the further evolution of state and society at all other levels (Du Toit 1995). Botswana's 40-year experiment with parliamentary democracy reveals that very little has changed and the same top-down and exclusionary approach to governance that characterised the pre-colonial and colonial eras still prevails, albeit in a new form.

\section{POLITICAL POWER AND AUTHORITY IN THE POST-COLONIAL ERA}

After almost 80 years of colonial rule Bechuanaland became an independent republic in 1966, under the name of Botswana. The advent of independence created a responsibility and a duty on the part of the new government to finish what the British had started, but left without completing, namely to create a unitary state. 'Tribal reserves' were replaced by district councils and the legislative council was replaced by a parliamentary system in which the country was divided into constituencies. The number of constituencies is based on the size of the population. The country adopted a Constitution with a Bill of Rights, that is, fundamental rights and freedoms of the individual. Also adopted was the British or Westminster-type electoral system known as first-past-the-post (FPTP).

In Western parliamentary democracies it is assumed that Parliament reflects and refracts the national-popular and/or the popular-democratic sentiment, and its deliberations will culminate in legislative and policy interventions to be enforced by the executive through a permanent rational-legal administration in accordance with the rule of law (Jessop 1990). This is supposed to be the essence 
of a competitive multiparty system: the electorate votes for parties or candidates on the basis of rational calculation that the candidates will enable it (the electorate) to realise its aspirations, whether these relate to economics, gender, or religion, and the party that wins the election is the party that has been able successfully to sell its policies and ideas to the electorate.

According to Mackenzie (1967) elections create a sentiment of popular consent and participation in public affairs, even when the nature of government is so complex as to be beyond the direct understanding of the ordinary citizen. Elections provide for orderly succession in government; for the peaceful transfer of authority to new rulers when the time comes for the old rulers to go, because of mortality or failure. Elections are seen as an important indicator of democracy because it is through them that citizens express their political preferences and their attitudes to rulers. But elections are more than just a change of guard. They presuppose that the new rulers have been chosen directly by the people, on the assumption or belief that they will exercise the political power and authority conferred on them in such a way that they will redress the grievances of the people who have elected them, be they economic, gender, ethnic or even religious grievances.

The expectations are that not only will the elected representatives articulate the aspirations of the electorate during the run-up to the election, once they have been elected they will formulate and implement policies and programmes that are in the best interests of the people who elected them. Between elections the electorate can participate in its governance through various institutions of civil society which enable it to monitor and evaluate the performance of the rulers. In Botswana the advent of an elected parliament and regular elections has not changed the top-down centralised governance and systemic exclusion of the people from popular participation in decision-making. A closer examination of the relationship between the executive and legislative branches of government reveals how this tradition persists.

\section{THE POWERS OF THE PRESIDENT}

The president of Botswana is the chief executive officer (CEO) of the republic. But unlike a CEO of a corporation who is accountable and reports to a board of directors (read Parliament), the president of Botswana enjoys enormous constitutional powers and is not accountable to Parliament (see below). According to s 47(1) of the Constitution of Botswana the executive powers of Botswana vest in the president. Section 47(2) states that in the exercise of his powers 'the President shall act in his own deliberate judgment and shall not be obliged to follow the advice of any other person or authority'. 
The powers of the president have been dealt with by Otlhogile (1998) and there is no need to repeat the information here; suffice it to mention that, as Otlhogile states, the president is both head of state and head of government and his or her wide ranging powers include the power to appoint and dismiss ministers; to appoint the commander of the armed forces, the commissioner of police, the permanent secretaries, the attorney general, the director of public prosecutions, ambassadors and high commissioners; to receive credentials from ambassadors; confer national honours; pardon offenders and exercise the prerogative of mercy. At the same time, all the state apparatuses or organs, such as the Botswana Defence Force, the Botswana Police Service, the civil service, and the proposed Directorate of Security and Intelligence, fall under the political control of a minister in the Office of the President.

A few concrete examples will suffice to illustrate the immensity of the president's powers. Section 7 of the Immigration Act gives the president the power to declare an immigrant or visitor to Botswana a 'prohibited immigrant'. The Act further provides that a person declared a 'prohibited immigrant' has no right to demand information about the grounds for such a decision, nor may such a person have recourse to the courts of law. This was brought into sharp relief recently when Professor Kenneth Good was declared a prohibited immigrant. Although Professor Good's lawyers tried to challenge his deportation, the Botswana Court of Appeal dismissed the case with costs.

The president also has the power to restrict the freedom of movement of citizens, as happened in 1978 when the president ordered that the passports of a Botswana National Front delegation to Havana, Cuba, should be withdrawn on grounds of national security (Otlhogile 1998). None of the members of the delegation was charged with any offence or even with contemplating commiting an offence. Botswana passports carry a cautionary note that 'This passport remains the property of the Government of Botswana and may be withdrawn at any time'.

Although the president may consult his Cabinet, and probably does so regularly, he or she is not obliged to do so, or even to agree with the Cabinet. Former President Sir Ketumile Masire reveals in his memoirs that in 1998 he disregarded the advice of his Cabinet colleagues and issued an executive order that a group of citizen contractors who had been having problems managing their accounts be given financial assistance, or a bail-out, as it was then called (Masire 2006). President Masire argues that in light of a serious slump in the building industry, he felt the negative effects of seeing so many citizens who had taken a risk fail because of general business condition would not be good for the development of Batswana entrepreneurs. 'And so I decided that small contractors needed to be given government assistance' ( $\mathrm{p} 84$ ). 
Normally the president is supposed to get information for decision-making from his officials, in this particular case from his minister of finance and development planning and the permanent secretary. Since both were opposed to the bail-out it is not very clear from where President Masire got the information that enabled him to make the decision. Speculation was rife that he was probably involved with one of the companies, or at least that a very close relative of his was. This incident strongly suggest that perhaps the president was not using his head, but his heart, in ignoring professional advice from the relevant ministry.

According to Good (2004), although the powers of the president of Botswana operate at various levels of society and government on a differentiated, episodic basis and are frequently held in reserve, their totality constitutes what he characterises as 'structured autocracy' that negates the principles of popular participation and openness.

What is interesting is that although the president wields enormous constitutional powers he or she is not directly elected. To become president all that is required is an endorsement by 1000 registered voters. Thereafter it is assumed that votes for the parliamentary candidates who have endorsed the presidential candidate are votes for that candidate. But once in power the president can dissolve a democratically elected parliament. There is no provision in the Constitution for the removal or impeachment of the president and although s 92 provides for the National Assembly to pass a vote of no confidence in the government, s 91(1) stipulates that the president may at any time prorogue Parliament (that is suspend its deliberations or even send parliamentarians home) and s 91(2) stipulates that the president may at any time dissolve Parliament.

The implications are clear: any motion of no confidence in government or any attempt to start proceedings to impeach the president can easily be pre-empted by the president's invocation of s 91(1) and / or s 91(2). At the same time no criminal or civil proceedings can be instituted against the sitting president. It is a moot point whether the spouse of the incumbent president can institute divorce proceedings against him or her or whether the mother of a president's child born out of wedlock can sue for child maintenance (Otlhogile 1998).

\section{POLITICAL REPRESENTATION AND PARLIAMENTARY DEMOCRACY}

Commentators like Molomo (2005) Sebudubudu (2005) and Sebudubudu \& OseiHwedie (2006) have posited that Botswana combines presidentialism and parliamentary democracy. The facts, however, strongly suggest that it is more presidentialism than parliamentary democracy. According to s 86 of the Constitution Parliament has the power to make laws for the peace, order and 
good government of Botswana, and this is exercised by means of a Bill passed by the National Assembly and assented to by the president. It is expected that when a Bill is presented to the president he either assents or withholds his assent. The president is required to assent to such a Bill within 21 days or to dissolve Parliament if there is a deadlock between the president and Parliament. The president's far-reaching powers, including the power to dissolve or suspend a democratically elected Parliament, have been a source of concern to Botswana parliamentarians and civil society. This concern was given expression on 8 March 1988 (some 22 years after independence) when Parliament passed a motion that:

... this Honorable House strongly urges government to take steps forthwith to ensure that Parliament as a supreme body in Botswana becomes an independent institution detached from the Office of the President where it has all the time been relegated to the lower status of a minor department (emphasis added).

But it was only in February 2002 (14 years after the motion was passed) that the speaker of the National Assembly appointed a task force to draft the terms of reference of a consultancy to assist in the implementation of the motion. On 10 December 2003 the task force, which comprised eight members of Parliament (MPs) and three eminent persons in the form of the speaker of the Canadian House of Commons, a former judge of the High Court of Botswana, a former attorney general of Gibraltar, the secretary general of the Parliament of North Westphalia, Germany, and a local legal consultant, presented its report to the speaker.

Among their main findings were that the Botswana Parliament currently lacks a clear statement of its role and functions and that there is a need to formulate and approve a parliamentary charter which clearly defines the role and functions of Parliament; that there is a need to amend the standing orders to better equip Parliament to carry out its role as 'watchdog' of the executive, and to establish a parliamentary service commission to manage and administer the affairs of Parliament and to de-link Parliament from the civil service. At the time of writing the 'Study on the Independence of the Parliament of Botswana', as the consultancy report has come to be known, has still not been presented to Parliament despite the fact that the 1988 motion asked government to take steps forthwith to ensure the supremacy of Parliament.

The motion on the independence of Parliament is just one of several passed by Parliament since its inception in 1966 and ignored by the executive. Others include one on the declaration of assets and liabilities of MPs, adopted in March 1996, which requested the executive to come up with a Bill to request all MPs, 
including Cabinet ministers, to disclose all their assets and liabilities in order to ensure transparency and avoid conflicts of interest.

The other motion that seems to have been ignored by the executive was on the tenure of office of MPs and councillors, adopted in August 1998, which requested the executive to introduce a Bill requiring any MP or elected councillor who wishes to cross the floor to vacate his or her seat and seek a fresh mandate from the electorate. Once adopted by Parliament the motion was referred to the Law Reform Committee (LRC) for further information gathering. The LRC addressed $32 \mathrm{kgotla}$ meetings on the issue and recommended that on the basis of the overwhelming evidence of national popular support for the motion, the executive should prepare the necessary legislation for its implementation (Botswana Government 1998/99). It is now eight year later and there is no indication that such legislation is being prepared and will come before Parliament any time soon.

Another interesting feature of Botswana's parliamentary system is that there is no correlation between the popular vote for different political parties and representation in Parliament. The skewed political representation in Parliament that emanates from Botswana's current FPTP electoral system is detailed elsewhere in this journal (see Molomo, p 21). As the results of the general elections since 1969 clearly show (see Table 1) opposition to the ruling BDP has risen steadily, from 31,5 per cent in 1969 to about 49 per cent in 2004.

The fact that the popular vote is not reflected in parliamentary seats shows that a large proportion of the subaltern voices have been excluded from parliamentary debates. In light of this it is surprising that commentators like Molomo (2005) Sebudubudu (2005) and Sebudubudu \& Osei-Hwedie (2006) can still argue that opposition parties remain weak, generally perform below expectations, and have not yet presented themselves as a credible democratic alternative. Other commentators, like Darnolf \& Holm (1999), have blamed, if not ridiculed, the opposition parties for being unable to get their act together, that is, to 'unite'. According to Darnolf \& Holm, Botswana's opposition parties have never committed themselves wholeheartedly to a strategy of coalition building for purposes of winning elections; that the de facto one-party system that prevails in Botswana is due mainly to this inability to form a pre-election coalition and they have squandered their chances by fighting among themselves. The formula for this electoral coalition is not suggested, leaving the reader to imagine that a mechanical amalgamation of opposition parties is probably what the authors have in mind.

According to these scholars there is no need to change the electoral system from FPTP to proportional representation (PR), and the opposition's objection to FPTP is little more than a recognition that it is unable to form an electoral coalition 


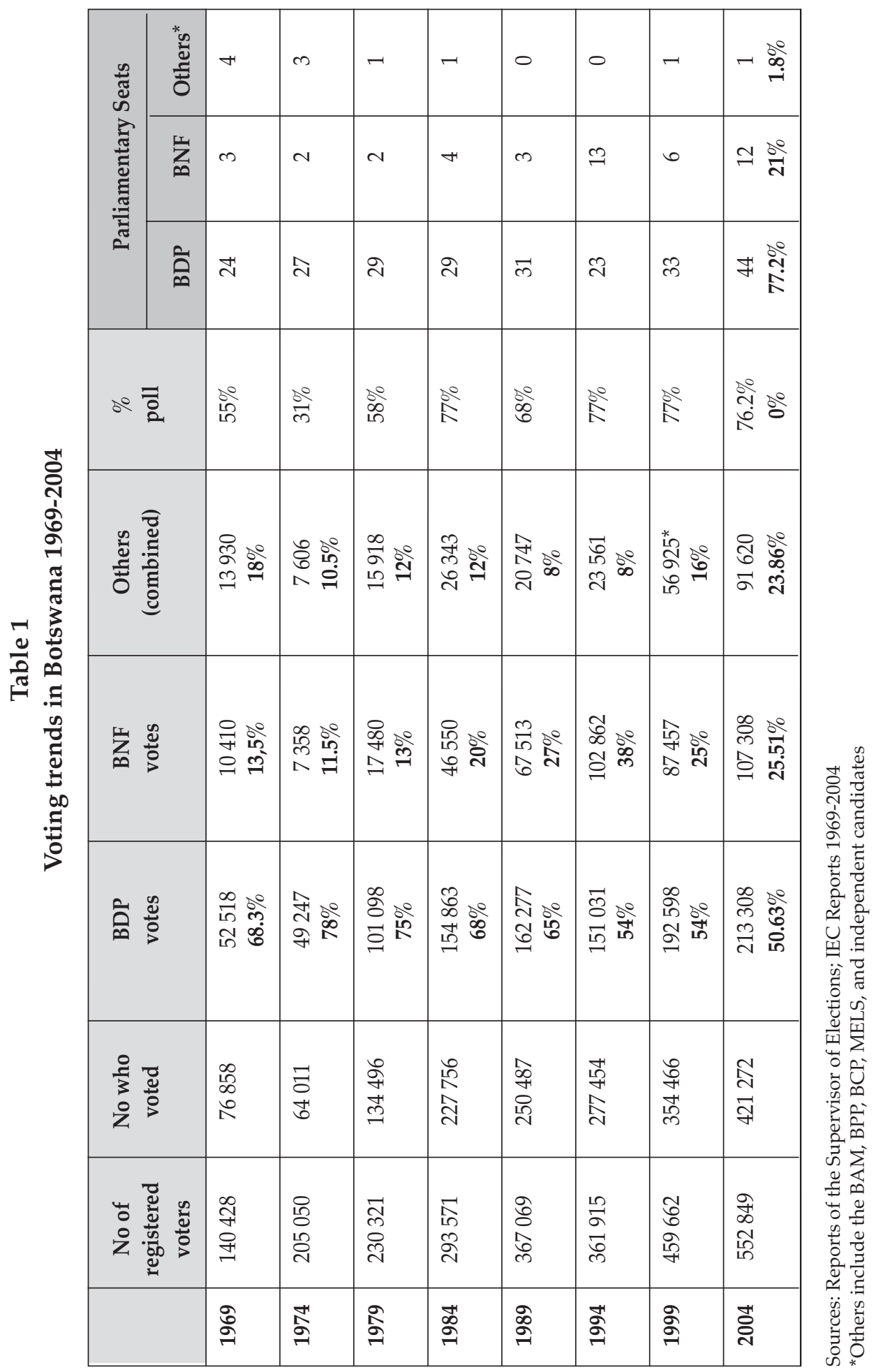


which would make FPTP a politically more attractive solution, especially given that the BDP is unlikely to agree to PR.

Two issues can be inferred from this position: firstly, there is an assumption that FPTP is an agreed model and the opposition does not like it because it is not working for it. The fact is that FPTP is a colonial inheritance, which is why it is also called the Westminster system. Secondly, it appears that the authors unwittingly conflate the ruling party interest and the national interest, that is, what is in the best interests of the ruling BDP is in the best interests of Botswana. But what is even more important about the commentaries of Darnolf \& Holm is that they seem to ignore the popular sentiment that democracy is really about political pluralism, whereby every shade of political opinion must be accommodated. The amalgamation of opposition parties into one big party capable of ousting the BDP will not result in political pluralism but in a two-party state. This is not necessarily good for democracy either. In the current era of 'parliamentary democracy', the subaltern groups are represented by the various opposition parties. The FPTP electoral system merely ensures that these voices remain unheard, like those of physically handicapped people who, in some societies, are kept hidden to avoid 'embarrassment' to the family. This can lead to an undercurrent of popular discontent, a process of internal combustion, which has sometime resulted in spontaneous explosions, as happened in Lesotho in the mid-1990s. These explosions occur when people lose confidence in parliament as a system of political representation and a forum for national-popular and or popular-democratic expression. FPTP creates a sense of marginalisation. A good example of this is a constituency in which the ruling party wins less than 50 per cent of the popular vote, with the remainder split between the opposition parties. In this case, the other 50 per cent or more is completely excluded.

In the 2004 general election about 12 constituencies went to the ruling party through the fragmentation of the opposition vote. The FPTP (or, as Darnolf \& Holm call it, single-member district plurality election) system simply does not work for Botswana, it excludes too many voices. Given that Parliament is supposed to be a vehicle for popular expression of all shades of political opinion, Botswana's Parliament excludes rather than includes popular opinions, a fact that undermines Parliament as the refraction of popular political participation. With new popular and inclusive forms of political representation taking root in the region, especially with the democratisation of South Africa, it appears that it will be more accurate to focus on the exclusionary aspects of Botswana's democracy, whose effect is to make it monolithic and give the impression that opposition to the ruling party is weak.

Yet another feature of Botswana's Parliament is that although it is enjoined by s 86 of the Constitution to make laws for the peace, order and good government 
of the country, what has been happening in practice is that it merely rubberstamps laws initiated by the executive. National development plans, national budget, Bills and other policy instruments always come from the executive and there has never been a private member's Bill (Sebudubudu \& Osei-Hwedie 2006). It is the executive rather than Parliament that ratifies treaties, conventions and protocols and on many occasions the executive, without consulting Parliament, has 'secretly' concluded agreements that bind and obligate the country.

An example is the 'Agreement Between the Government of the United States of America and the Government of the Republic of Botswana Regarding the Surrender of Persons to International Tribunals', signed in 2003. According to this agreement the Botswana government (read the executive) agreed with the USA not to surrender current or former US employees, including military personnel, to the International Criminal Court. More recently the government entered into a 25-year agreement with De Beers Mining Company concerning that company's operations in Botswana. When some parliamentarians asked question about this secret agreement and its implications for the country, they were simply told that the matter was sensitive and that the government would not do anything that might be harmful to the country.

The executive has also unilaterally chosen to ratify or not ratify certain international conventions, without consulting Parliament. The reasons for such ratification, or withholding of ratification, remain confidential. One example is the government's refusal or reluctance to accede to the African Peer Review Mechanism (APRM). In November 2006 when an MP asked the Minister of Presidential Affairs and Public Administration whether the government intended to sign the APRM, and if so, when, and if not, why not, he was simply told that accession to the APRM is voluntary, that the APRM is still evolving and the question of accession to it is still being considered (by the executive) (Botswana Gazette 29 November 2006). It is anybody's guess why a country like Botswana, which has received worldwide accolades for its democracy and good governance, should be reluctant to ratify or accede to the APRM, or even have the matter debated by Parliament. Could this mean that the executive has something to hide?

\section{CONCLUSION}

Societies are dynamic, their ever-changing context an outcome of a changing socio-economic and political landscape. Societies also carry 'excess baggage' or vestiges of their past social practices. It can be argued that as a society develops or moves forward there are both continuities and discontinuities in its life and there is no such thing as a 'clean break with the past'. Botswana is no exception. 
The above analysis of the dynamics of the Tswana political institution reveals some interesting continuities and discontinuities. The main continuity of the three periods is the top-down authoritarian exercise of political power and the systemic exclusion of the subaltern social forces from political participation; the main discontinuity is the changing context within which this power is exercised. I shall highlight each of these in turn.

\section{The Continuity}

There is a common denominator in the immense executive powers vested in the kgosi in the pre-colonial area, in the resident commissioner in the colonial era, and in the president in the post-colonial era. In the pre-colonial period, the kgosi could consult the kgotla, but the advice was not binding. During the colonial period, the resident commissioner ruled by 'proclamation', was not obliged to take the advice of the advisory councils, and the 'proclamations' were not based on the deliberations of the advisory councils. In the current phase of parliamentary democracy the country is ruled by the executive president who, according to the Constitution, may act in his own deliberate judgement and is not obliged to follow the advice of any other person or authority. The other common denominator of these three periods is that all the systems operate under rulers who were not elected but had very extensive executive powers.

Finally, all three periods share the exclusion of the voices of what can only be described as subaltern social groups. To be sure, this exclusion is systemic rather than systematic, that is to say, it derives from Botswana's electoral system. While there is a saying in Setswana that 'mafoko a kgotla a mantle otlhe [all opinions are welcome]' historical evidence reveals that it was in fact only the closest advisors of the kgosi, such as paternal uncles and headmen, who had had any influence during the kgotla debates. The subaltern social groups such as commoners, women, settlers and minorities, could, in principle, speak; in practice this was well nigh impossible because of their social status.

\section{The Discontinuity}

During the pre-colonial period the kgosi ruled over a society in which the economy was still traditional, the population illiterate, society undifferentiated, with a simple division of labour. Social cohesion was the outcome of collective communal conscience rather than political consensus. Under colonial rule colonialists used the system of indirect rule and the top-down exercise of power and authority was mostly implemented through the kgosi. A good example was that of tax collection. In order to make tax collection more effective British colonial state 
officials enlisted the support of the chiefs by offering them 10 per cent commission on tax collected, and the more tax returns the chief brought the more he received in commission (Mogalakwe 2006). In this way tax collection was legitimated through the acquiescence or co-option of native chiefs. In the current post-colonial era an elected, but emasculated Parliament is the main form of legitimating the exercise of political power and authority. Although it is Parliament that approves legislation and policy, it is always the executive that initiates it and on occasions when ruling party backbenchers have refused to rubber-stamp the initiatives of the executive they have been called to the ruling party parliamentary caucus, where they have been warned against saying things that might embarrass 'their' government, meaning the executive, and have been politely asked to toe the line.

Having said all this, though, it is important to note that what is happening in Botswana's 'parliamentary democracy', especially the legislative/executive relations, is in a way consistent with the observation made by scholars such as Poulantzas (1978), who have argued that even in the advanced bourgeois democracies there has been irresistible centralisation and concentration of power in the executive and at the expense of the Parliament; a general tendency to exclude the masses from elaborating state policy through their parliamentary representation; and that the elected Parliament has been emasculated.

The case study of Botswana provides compelling evidence of how a democratically and popularly elected Parliament can be emasculated and marginalised, even in a democracy, and can become a talkshop, with the real business of the state taking place in the executive and the bureaucracy. The irony is that this is happening against the background of a plethora of praise poems about Botswana being a shining example of functioning governance, multiparty liberal democracy; an exception that confounds generalisations, and a hopeful model for Africa (Stedman 1993).

\section{- REFERENCES}

Botswana Gazette. 29 November-5 December 2006.

Botswana Government 1998/99. Report of the Law Reform Committee for the Parliamentary Year 1998/99. Gaborone: Government Printer.

- 2004. Report to the Minister of Presidential Affairs and Public Administration on the 2004 General Elections. Gaborone: The Independent Electoral Commission.

Crowder, M. 1988. The Flogging of Phineus Macintosh: A Tale of Colonial Folly and Injustice, Bechuanaland, 1933. New Haven: Yale University Press.

Darnolf, S \& J Holm. 1999. 'Democracy Without a Credible Opposition - The Case of Botswana. The Journal of African Policy Studies 5(2\&3). 
Du Toit, P. 1995. State Building and Democracy in Southern Africa - Botswana, Zimbabwe and South Africa. Washington, DC: United States Institute for Peace Press.

Good, K. 2004. Realising Democracy and Legitimacy in Southern Africa. Pretoria: Africa Institute of South Africa.

Gosset, C W. 1986. 'The Civil Service in Botswana: Personnel Policies in Comparative Perspectives'. Unpublished Doctoral Thesis, Stanford University.

Gramsci, A. 1973. Selection from Prison Notebooks. International Publishers.

Jary, D \& J Jary. 1991. Collins Dictionary of Sociology. Glasgow: HarperCollins.

Jessop B. 1990. State Theory: Putting Capitalist States in their Place. Cambridge: Polity Press.

Mackenzie, W J M. 1967. Free Elections. George Allen and Unwin Ltd.

Masire, Q K J. 2006. Very Brave or Very Foolish? The Memoirs of an African Democrat. Gaborone: Macmillan.

Maylam, P. 1980. Rhodes, the Tswana, and the British. Westport, CT: Greenwood Press.

Mgadla, P T \& A Campbell. 1989. 'Dikgosi. Dikgotla and the Protectorate Administrators'. In J Holm \& P Molutsi (eds). Democracy in Botswana. Gaborone: Botswana Society and Macmillan.

Mogalakwe, M. 1997. The State and Organized Labour in Botswana-Liberal Democracy in Emergent Capitalism. Aldershot: Ashgate.

— 2006. 'How Britain Underdeveloped Bechuanaland: A Brief Critique of the Political Economy of Colonial Botswana. Africa Development 31(1).

Molomo, M. 2005. 'Electoral System and Democracy in Botswana'. In Z Maundeni (ed). 40 Years of D emocracy 1965-2005. Gaborone: Mmegi.

Otlhogile, B. 1998. 'The President: His Office, Functions and Powers. In W A Edge \& M Lekorwe (eds). Botswana: Politics and Society. Pretoria: J. L. Van Schaik. Parsons, N. 1975. 'The Economic History of Khama's Country, 1844-1930'. In R Palmer and N Parson (eds). The Roots of Rural Poverty in Central and Southern Africa. London: Heinemann.

Poulantzas, N. 1978. State, Power and Socialism. London: Verso.

Sebudubudu, D. 2005. 'Botswana - Democracy Curtailed?' Southern African Yearbook of International Affairs. Johannesburg: SAIIA.

\& B Osei-Hwedie. 2006. 'Pitfalls of Parliamentary Democracy in Botswana'. Afrika Spectrum 41(1).

Stedman, S J. 1993. 'Introduction'. The Political Economy of Democratic Development. Boulder: Lynne Rienner Publishers.

Stevens, R P. 1975. Historical Dictionary of the Republic of Botswana. Metuchen, NJ: The Scarecrow Press Inc. 